\title{
Genotypic Variability of the Components and their Effects on the Rice Yield: Correlation and Path Analysis Study
}

\author{
Md. Rokonuzzaman*, Mohammed Salim Zahangir, Md. Imam Hussain, \\ Md. Sharkhawat Hossain \\ Department of Statistics, University of Chittagong \\ Chittagong-4331, Bangladesh
}

Received: 14 January 2008. Accepted: 21 August 2008.

\begin{abstract}
Twenty modern Boro rice varieties were evaluated with a view to find variability and genetic association for grain yield and yield components characters. Genotypic and Phenotypic correlation among these characters were computed. Both genotypic and phenotypic correlation coefficients were significant between plant height and number of effective tillers per plant followed by panicle length. There was a positive significant correlation between yield and number of effective tillers per plant followed by percent filled grain per panicle. Path coefficient showed that number of effective tiller per plant and plant height are the characters that contribute largely to grain yield.
\end{abstract}

Key-words: Path coefficient, genotypic correlation, phenotypic correlation, variability.

\section{Introduction}

Rice is the staple food grain of Bangladesh and major source of caloric and protein. It shares $95 \%$ of the cereal consumption. FAO recommends that the need of cereal consumption per people per day is $454 \mathrm{gm}$. At present, Bangladesh needs about 25 million-ton food grains per year to feed her 146 million people. Although Bangladesh is now on the verge of attaining self-sufficiency in cereal production, there is still a major gap between the production and demand in the country. Bangladesh Rice Research Institute (BRRI) was established early seventies to develop high yielding variety to meet food demand for increasing population of Bangladesh. Moreover population in the country is increasing drastically and land under agriculture field decreasing day by day due to rapid urbanization and development of industry and infrastructure. If this situation continues people have to face stiff challenge to feed the numerous hungry mouths of the future. Presently the average yield of MV Boro rice is $3.47 \mathrm{t} / \mathrm{ha}$
(BBS 2005). To solve the food deficit, rice production should be increased. Grain yield is the main factor for the determining the improvement of a cereal crop. It is a quantitative character, which is influenced by a number of yield contributing characters i.e. number of effective tillers per plant, days to $50 \%$ flowering, Plant height, 1000-grain weight, panicle per plant, percent filled grain etc. Sarker et al. (2001) suggested that for cold tolerance rice, Grains/Panicle showed highest response to selection yield through indirect selection along with maximum relative efficiency. The present study therefore aimed to assess phenotypic and genotypic association between various components of grain yield to provide selecting irrigated Boro rice genotypes.

\section{Materials and methods}

\section{Material}

Twenty modern irrigated Boro rice varieties developed by BRRI were used in this study. The

* Corresponding Author:Tel.: +88 01716 252129; +88 031 681950. E-mail address: mrzcu@yahoo.com; mrzamancu@yahoo.com 
names of the varieties are BR1, BR2, BR3, BR6, BR7, BR8, BR9, BR12, BR14, BR15, BR16, BR17, BR18, BR19, BR26, BRRI Dhan27, BRRI Dhan28, BRRI Dhan29, BRRI Dhan35 and BRRI Dhan36.

\section{Methods}

These varieties were grown at BRRI farm during the Boro season of 2004 using Randomized Complete Block Design in 3 replications with $20 \mathrm{~cm} \times 20 \mathrm{~cm}$ spacing between rows and plants. Recommended fertilizer dozes were applied in the experimental field and all necessary cultural practices were used as and when necessary during the whole growing period.

\section{Data collections}

The following components were taken from randomly selected plant and data were taken from these selected plant.

- Plant height $(\mathrm{cm})$

- Days to $50 \%$ flowering

- Number of effective tiller per plant

- Filled grain per panicle (\%)

- Panicle length $(\mathrm{cm})$

- 1000-grain weight (gm)

- Yield (ton/ha).

\section{Data analysis}

The analysis of variance for all above-mentioned varieties was performed following Stell and Torrie (1980). Results for ANOVA were considered significant at $p<0.05$ or $p<0.01$. Genotypic and phenotypic correlation coefficients were calculated as according to Miller et al. (1958) and Hanson et al. (1956). Genotypic and phenotypic coefficients of variation were estimated as said by Singh and Chaudhary (1977). Path co-efficient analysis provides such success (Rahman et al., 1983) giving the partition of correlation co-efficient into direct and indirect effects. The methodology proposed by Dewey and Lu (1959) was used to perform path analysis in grain yield and some yield contributing characters keeping grain yield as resultant variable and other yield contributing characters as causal variables.

\section{Results and discussions}

Mean and treatments effects are shown in Table 1. All the treatment effects are highly significant. The difference between genotypic coefficient of variation (GCV) and phenotypic coefficient of variation $(\mathrm{PCV})$ were very low for all the characters under this study (Tab. 1), which suggested that these characters were less influenced by the environment.

The highest GCV was found for effective tiller number per plant $(23.72 \%)$ followed by plant height $(16.35 \%)$.Yield $(15.92 \%)$ and 1000 -grain weight $(11.57 \%)$ also had higher GCV. For PCV, effective tiller number per plant was also showed highest value and PCV of yield was the second highest and followed by plant height. Hossain et al. (2003) and Singh and Chaudhary (1996) also found similar results. Heritability in broad sense (\%) was the highest for plant height and followed by days to $50 \%$ flowering and it was lowest for yield and followed by panicle length. This result partially conformed by Biswas et al. (2000).

The association of grain yield with yield contributing characters and also the association among these characters were estimated by genotypic and phenotypic correlation coefficients (Tab. 2). Data on correlation coefficients

Table 1. Estimation of genetic parameters for rice yields and yields contributing characters.

\begin{tabular}{|c|c|c|c|c|c|c|}
\hline \multirow[t]{2}{*}{ Characters } & \multirow[t]{2}{*}{ Mean } & \multicolumn{2}{|c|}{ Mean Square } & \multicolumn{2}{|c|}{ Coefficient of variation (\%) } & \multirow{2}{*}{$\begin{array}{c}\text { Heritability }(\%) \\
\text { in broad } \\
\text { sense }\left(\mathrm{h}^{2}\right)\end{array}$} \\
\hline & & Treatment & Error & $\begin{array}{c}\text { Genotype } \\
(\text { GCV) }\end{array}$ & $\begin{array}{c}\text { Phenotype } \\
\text { (PCV) }\end{array}$ & \\
\hline $\mathrm{PH}$ & 98.70 & $785.56^{* *}$ & 3.95 & 16.35 & 16.48 & 98.6 \\
\hline $\mathrm{TN}$ & 12.65 & $30.99 * *$ & 4.00 & 23.72 & 28.51 & 69.2 \\
\hline PL & 21.96 & $2.69 * *$ & 0.61 & 3.80 & 5.19 & 53.4 \\
\hline GW & 22.88 & $21.34 * *$ & 0.30 & 11.57 & 11.82 & 95.8 \\
\hline FG & 65.30 & $116.97 * *$ & 16.68 & 8.85 & 10.84 & 66.7 \\
\hline FL & 124.40 & $123.88 * *$ & 0.77 & 5.15 & 5.20 & 98.2 \\
\hline YD & 4.25 & $1.85^{* *}$ & 0.48 & 15.92 & 22.74 & 49.0 \\
\hline
\end{tabular}

*, ** indicate the level of significance at $5 \%$ and $1 \%$ respectively. PH-Plant height, TN-Number of effective tiller per plant, PLPanicle length, GW-1000-grain weight, FG-Filled grain per panicle, FL-Days to $50 \%$ flowering, YD-Yield. 
Table 2. Genotypic (upper right) and phenotypic (lower left) correlation coefficients between yield and yield contributing characters for rice.

\begin{tabular}{lccccccc}
\hline & PH & TN & PL & GW & FG & FL & Yield \\
\hline PH & 1.000 & $-0.847^{* *}$ & $0.308^{*}$ & 0.186 & -0.161 & -0.158 & $-0.300^{*}$ \\
TN & $-0.683^{* *}$ & 1.000 & $-0.505^{* *}$ & $-0.214^{*}$ & $0.251^{*}$ & -0.016 & $0.533^{* *}$ \\
PL & 0.227 & $-0.349^{* *}$ & 1.000 & $0.394^{* *}$ & -0.133 & -0.071 & $-0.254^{*}$ \\
GW & 0.181 & -0.183 & $0.275^{*}$ & 1.000 & 0.167 & 0.102 & 0.203 \\
FG & -0.134 & 0.212 & -0.239 & 0.107 & 1.000 & 0.042 & $0.514^{* *}$ \\
FL & -0.156 & -0.015 & -0.019 & 0.092 & 0.024 & 1.000 & -0.081 \\
YD & -0.219 & $0.500^{* *}$ & -0.121 & 0.127 & $0.429^{* *}$ & -0.042 & 1.000 \\
\hline
\end{tabular}

*, ** indicate the level of significance at $5 \%$ and $1 \%$ respectively. PH-Plant height, TN-Number of effective tiller per plant, PLPanicle length, GW-1000-grain weight, FG-Filled grain per panicle, FL-Days to 50\% flowering, YD-Yield.

among the yield contributing characters revealed that in most of cases the values of genotypic correlations were higher than the corresponding phenotypic correlation coefficients. Effective tiller number per plant and percent filled grain per panicle had significant positive genotypic and phenotypic correlation coefficients with rice yield. But plant height and panicle length had negative significant correlation with effective tiller number per plant. This result is similar with Rasheed et al. (2002).

Figure 1 showed the genotypic Correlation and Figure 2 revealed the phenotypic Correlation among the rice yield and yield contributing characters. From the diagram it is observed that numbers of genotypic correlation coefficients are more statistically significant than the numbers of phenotypic correlation coefficients. Further it is shown that effective tiller number per

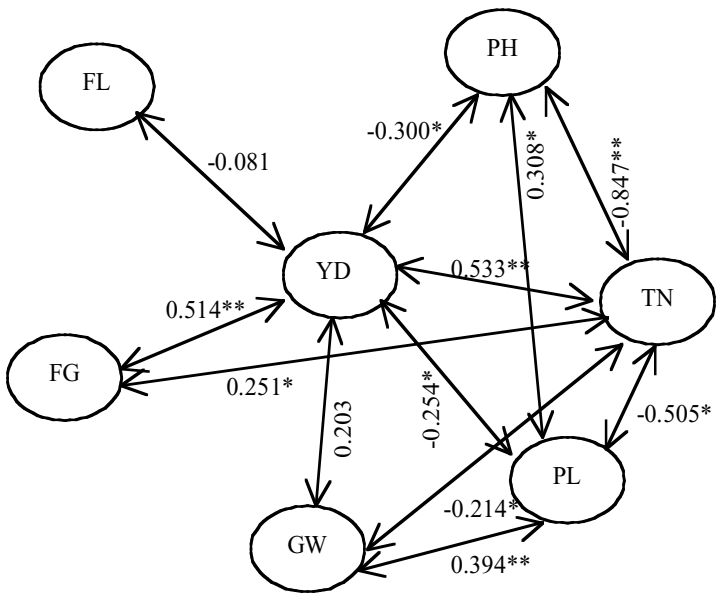

plant had significant correlation with plant height, panicle length and 1000-grain weight for both of genotypic and phenotypic but had a significant correlation with filled grain for only genotypic.

Path coefficient analysis based on genotypic correlation (Tab. 3) showed effective tiller number per plant explained the highest positive direct effect on grain yields. The indirect effect of effective tiller number per plant though plant height was negative but considerable. Similar results have also been reported by Panwar et al. (1989) and Sarker et al. (2001). Although plant height exhibited high positive direct effects followed by 1000 -grain weight, but the indirect effects of plant height though effective tiller number per plant is negatively high and considerable. Panicle length showed negligible negative direct effects but had considerable negative in-

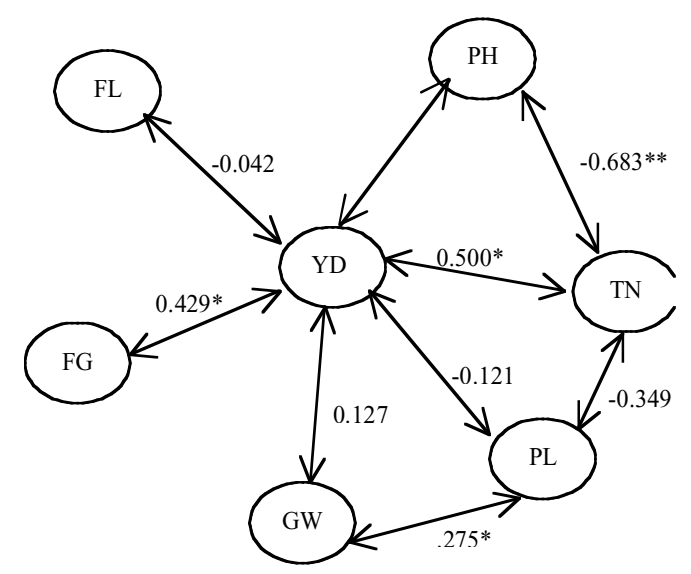

Figure 1. Diagram of Genotypic Correlation. Figure 2. Diagram of Phenotypic Correlation.

$*, * *$ indicate the level of significance at $5 \%$ and $1 \%$ respectively. 
Table 3. Path coefficients analysis of genotypic correlation showing direct and indirect effects of yield components on rice grain yield.

\begin{tabular}{|c|c|c|c|c|c|c|c|}
\hline & $\mathrm{PH}$ & $\mathrm{TN}$ & PL & GW & FG & FL & $\begin{array}{r}\text { Correlation } \\
\text { with yield }\end{array}$ \\
\hline $\mathrm{PH}$ & 0.401 & -0.340 & 0.123 & 0.075 & -0.064 & -0.063 & $-0.262 *$ \\
\hline $\mathrm{TN}$ & -0.707 & 0.835 & -0.422 & -0.179 & 0.209 & -0.080 & $0.516^{* *}$ \\
\hline PL & -0.020 & 0.033 & -0.065 & -0.025 & 0.009 & 0.011 & -0.187 \\
\hline GW & 0.066 & -0.104 & 0.140 & 0.354 & 0.059 & 0.036 & 0.168 \\
\hline FG & -0.049 & 0.076 & -0.041 & 0.051 & 0.303 & 0.013 & $0.473 * *$ \\
\hline FL & 0.009 & 0.001 & 0.004 & -0.006 & -0.002 & -0.158 & -0.064 \\
\hline
\end{tabular}

Residual effects $\mathrm{R}=0.445$.

Italics figures indicate the direct effects, *** indicate the level of significance at $5 \%$ and $1 \%$ respectively. PH-Plant height, TNNumber of effective tiller per plant, PL-Panicle length, GW-1000-grain weight, FG-Filled grain per panicle, FL-Days to $50 \%$ flowering.

direct effect though effective tiller number per plant. The direct effect of panicle length was not appearing good though its indirect effects via effective tiller number per plant, 1000-grain weight and plant height were well pronounced. Haque et al. (1991) also found similar result.

In conclusion, the findings of this research showed that the highest coefficient of variation for both genotypic and phenotypic occurs in effective tiller number per plant (Tab. 1). Genotypic correlation coefficients were generally higher than corresponding phenotypic correlation coefficients (Fig. 1 and 2). Both genotypic and phenotypic correlation showed that effective tiller number per plant and percent filled grain had positive significant correlation with grain yield. Although plant height and panicle length revealed negative significant correlation with grain yield. Path analysis based on genotypic correlation coefficient demonstrated that, effective tiller number per plant; plant height and 1000 grain weight have positive significant effect on grain yield (Tab. 3). Therefore the results suggested that effective tiller number per plant; plant height, 1000 grain weight and percent filled grain are yield contributing characters for identification of new plant types of rice.

\section{References}

Bangladesh Beuroe of Statistics, 2005. Handbook of Agricultural Statistics. Ministry of Agriculture. Bangladesh.

Biswas P.S., Prashad B., Dewan S.B.A. 2000. Variability, character association and path analysis in rice (Oryza Sativa L.). Bangladesh J. of Plant Breed. Genet., $13,1: 19-25$.
Dewey D.R., Lu K.I. 1959. A correlation and path coefficient analysis of components of crested wheat grass seed production. Agron. J., 52:515-518.

Hanson C.H., Robinson H.F., Comstock R.E. 1956. Biometrical studies of yield in segregating population of Korean lespedeza. Agric. J., 48:268-272.

Haque M.E., Baset M.A., Zeenat Z., Miah N.M. 1991. Path co-efficient analysis of seven characters in Cold tolerant rice. Bangladesh Rice J., 2(1,2):1-7.

Hossain M.A., Haque M.E. 2003. Genetic variability and path analysis in rice genotype. Bangladesh J. Pl. Breed. Genet., 16,1:33-37.

Miller P.A., Williants C., Roginson H.F., Comstock R.E. 1958. Estimates of Genotypic and environmental variance and covariance and their implication in section. Agron. J., 50:126-131.

Panwar D.V.S., Bansal M.P., Naidu M.R. 1989. Correlation and path coefficient analysis in advanced breeding lines in rice. Oryza, 26:396-398.

Rahman A., Das M.L., Khan M.H.R. 1983. Path coefficient analysis of yield component in Brassica species. Indian J. Agric. Sci., 53:195-197.

Rasheed M.S., Sadaqat H.A., Babar M. 2002. Correlation and path co-efficient analysis for yield and its components in Rice (Oryza Sativa L.). Asian J. of Pl. Sci., 1,3:241-244.

Sarker U., Biswas P.S., Prasad B., Miah M.A.K. 2001.Corrleted response, relative selection efficiency and path analysis in cold tolerant rice. Bangladesh J. Pl. Breed. Genet., 14,2:33-36.

Singh R.K., Chaudhary B.D. 1977. Biometrical methods in quantitative genetic analysis. Kalyani Publications, New Delhi, India.

Singh R.K., Chaudhary B.S. 1996. Variability heritability and genetic advance in cultivars of rice (Oryza Sativa L.). Crop Res. Hishar., 12,2:165-167.

Steel R.G.D., Torrie J.H. 1980. Principles and procedures of statistics. McGraw Hill Books Co. Inc. Newyork, USA. 